JOANNA KLIMOWICZ

\title{
Komfort zamieszkania we współczesnym miejskim domu
}

\section{The comfort of living in a modern urban home}

\section{Streszczenie}

Wspótczesne miasta borykają się z wieloma problemami. Jednymi z bardzo istotnych problemów ostatnich lat są: wzrastajacy pozion 作 kancy borykaja się z tymi problemami. Dażac do poprawy warunkow egzystencji w miastach wprowadza się udogodnienia majace na celu ochronę wspótczesnego człowieka, zwłaszcza w domu, który ma stanowić jego schronienie. fort zamieszkania. Przedstawienie współtzesnyych rozwiazzań mających na celu jak najilepszą ochronę mieszkańców oraz zapewnienie im odpowiednich warunków życia.

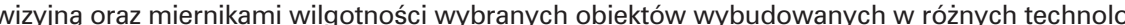
giach, pokazuia jak żle dobrane materiały wykończeniowe moga wpływać na pogarszanie sie komfortu mieszkania. Prawidtowy dobor materiatów budowlanych oraz odpowiednie ich zastosowanie przyczynia się do niwelowania strat cieplnych, a co za tym idzie niwelowania występującego $w$ miastach efektu Miejskiej Wyspy Ciepła. Mniejsze zapotrzebowanie na energię, wpływa na Wyniki badań stanowić będą podstawę do dalszej pracy zwiazzanej z obserwacją zachowań budynków wybudowanych w różnych

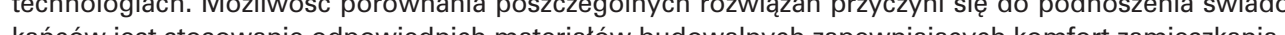

\section{Abstract}

Contemporary cities are struggling with many problems. The most important problems of recent years are: the increasing level of pollution and rising temperatures in central parts of cities (the effect of the Urban Heat Island). The inhabitants often have to deal
with these problems. Striving to improve the living conditions in the city facilities are introduced to protect the contemporary man especially in the house, which is to be his shelter.

The subject of the article is to illustrate on selected examples of bad and beneficial material solutions affecting the comfort of living. 作

The research carried out on thermal imaging cameras and humidity meters of selected objects built in various technologies, show how poorly selected finishing materials can affect the deterioration of the comfort of living.

Proper selection of building materials and their proper application contribute to the reduction of heat losses and thus to the reduction The efrect of the City Heat sland in cities. Lower demand for energy also contributes to the reduction of heat losses and air pollution resulting from excessive heating parameters.

The results of he dents to use appropriate building materials ensuring the comfort of living

Słowa kluczowe: Komfort życia, dom miejski, warunki życia wi
Key words: Living comfort, urban home, living conditions

\section{Wstęp}

Zagadnienia związane z szeroko pojętym rozwojem miast, już na przełomie XIX i XX w. zajmowały się jakością życia w mieście. Wtedy głównie odnoszono się pujący coraz ekspansywniej rozwój przemysłu sięgający II fazy rewolucji przemystowej' wpłyną na potrzebe myślenia o kształtowaniu zdrowego środowiska miejskiego. W połowie XX W. rozważania związane ze zdrowym środowiskiem zaczęły odnosić się już do samego komfortu zamieszkania, zarowno jednostki, jak i społeczen-

\section{Introduction}

At the turn of the $19^{\text {th }}$ and $20^{\text {th }}$ centuries, issues related to urban development were concerned with the quality of life. At that time, the problem of "healthiness" of city inhabitants was mainly referred to. The expansive development of industry during the second phase of the industrial revolution', necessitated the need to think about shaping a healthy urban environment. In the middle of the twentieth century, considerations related to healthy environment began to refer to the stwa. Aspekt komfortu uzależniano wtedy od satysfakcj life). Istotne wtedy byly. bezpieczenistwo, kontakty spoleczne, minimalizowanie negatywnych aspektów życia. Zwracano szczególnie uwagę na występujące na danych obszarach problemy.

Rozważania dotyczące zagadnienia komfortu powinn się rozpocząc od analizy samego słowa "komfort", którego zastosowanie możemy spotkać $\mathrm{w}$ odniesieniu do wielu dziedzin życia. Sam słownik języka polskiego tak opisuje słowo "komfort"

1. Ogół warunków zewnętrznych zapewniajacych człowiekowi wygodę, odznaczających się dostatkiem $i$ elegancją;

2. Stan zaspokojenia potrzeb fizycznych i psychicznych oraz braku klopotów.

作 jący sposób:

1. Comfort noun - a pleasant feeling of being relaxed and free form pain;

2. Comfort noun - the state of feeling better after feeling sad or worried, or something that makes you feel better in this way;

3 . Comfort noun - the state of having a pleasant life with enough money for everything that you need:

4. Comfort noun - something that makes your life easy and pleasant;

5. Comfort verb - to make someone feel better when they are sad or worried.

Jak widać z samych definicji „komfort” może być postrzegany w różny sposób, a samo słowo czasem może być po prostu nadużywane w różnych kontekstach. Dla wielu osób komfort kojarzy się z wymienionym powyżej definicjami, jednakże jest pojęciem subiektywnym. Jest związany $z$ indywidualnym spojrzeniem $n$ swiat, indywidualnym odczuwaniem oraz bodzcam które do nas docieraja. Każdy człowiek ma inne prog np. komfortu cieplnego, odczuwania, potrzeb, a takze in dywidualnej sensoryki. Jedni czują się komfortowo, gdy temperatura powietrza przewyższa $25^{\circ} \mathrm{C}$, podczas gdy dla innych komfort ciepiny jest spełniony juz przy $20^{\circ} \mathrm{C}$. Podobnie jest w okresach zimowych jednym odpowiadają temperatury ujemne, inni wecz czekaja aż okres zimowy się skonczy. Wedlug prof. Tomasz Wišniewskiego Stan komoru cieplnego czlowieka to stan jego zrownoważonego bilansu cieplnego $z$ otoczeniem przy jed-

Podobne miejsca ziatej czy dziesiatej kondygnacii w samym centrum miasta jest najepszym rozwiazaniem, dla innych tylko własny duży dom poza miastem jest spetnieniem ma rzeń Psychologiczne podeśście do komfortu rozważa tez profesor psychologii Augustyn Bańka w pracy Jakośc życia w mieście" wskazujac na "obiektywn i isubiektywna ocene poszczególnych sfer życia $z$ uwzględnieniem wagi, jaka jednostka przywiazuje do poszczególnych aspektów (sfer) życia".

Istotnym, niestety negatywnym, czynnikiem wpływających na komfort życia w dzisiejszym świecie sa postępujace zmiany klimatu, obserwowane i poddawane comfort of living, both for the individual and the sociisfaction from living in the living environment (quality of life). At that time, security, social contacts, minimizing negative aspects of life were important. Attention was drawn to problems occurring in given areas.

The consideration of the issue of comfort should begin with an analysis of the word "comfort" which can be applied to many areas of life. The Polish dictionary describes the word "comfort" as:

1. General external conditions ensuring human com fort, characterized by abundance and elegance;

2. State of satisfaction of physical and mental needs and absence of problems. ${ }^{2}$

While in the English dictionary, the word "comfort" is defined as follows:

1. Comfort noun - a pleasant feeling of being relaxed and free form pain

2. Comfort noun - the state of feeling better after feeling sad or worried, or something that makes you feel better in this way

3. Comfort noun - the state of having a pleasant life with enough money for everything that you need 4. Comfort noun - something that makes your life easy and pleasant

5. Comfort verb - to make someone feel better when they are sad or worried ${ }^{3}$

As we see, "comfort" by definition can be seen in different ways, and the word itself can sometimes be abused in different contexts.

For many people, comfort is associated with the above definitions, however, it is a subjective concept. Is related to the individual's view of the world - the individual feeling and the stimuli that reaches us. Each person has different thresholds, e.g. thermal comfort sensation, needs and individual sensory perception. Some people only feel comfortable when the air temperature exceeds $25^{\circ} \mathrm{C}$, while for thers the thermal comfort is fulfilled already at $20^{\circ} \mathrm{C}$ The same is true in winter periods, some people are comfortable in the colder temperatures, and others cannot wait for the winter period to end as soon as possible. According to Prof Tomasz Wiśniewski, "The state of human thermal comfort is the state of his sustainable heat balance with the environment while lacking local discomfort."

People behave similarly when choosing their place of residence. For some people, a three-room apartfresidence. For some people, a three-room apartis the best solution For others, owning a large house outsic soution For others, owning a large house outside the city is a dream come true. The psychogeach to comfort is also considered by the "Ofs of psychology Augustyn Banka in his work "Quality of life in the city" pointing to "objective and taking into ecaluation of individual spheres of life, attaches to particular aspects (spheres) of life". 
badaniom we wszystkich niemal zakątkach świata. Coraz częściej słyszy się o wzrastających temperaturach, występowaniu nietypowych zjawisk pogodowych. Zjawisk takie jak huragany, obfite deszcze czy ekstremalne temperatury nie są korzystne dla człowieka. Wywołane wzrostem temperatur pustynnienie przyczyniło się też do masowych migracji ludnosci z terenów rolniczych do miast. $Z$ analiz przeprowadzanych przez EEA ${ }^{6}$ czy IPCC $^{7}$ wynika, iż $w X X I$ wieku będziemy się stykali z coraz większą ilością anomalii pogodowych, które będą miały bezpośredn wpływ na nasze życie. Wzrost ludności w miastach powoduje wzrost zapotrzebowania na obszary zurbanizowane (miejsca pracy i miejsca zamieszkania), to prowadzi do Wzrostu transportu, problemów z zanieczyszczeniem powietrza i wystepowania coraz czessciej obserwowanego dzisiejzego rozy misto jak nailepo zzezula jak najepsze zabezpieczenie mieszkanców przed ewenDzisiejsze spoleczeństwa, zamieszkujace miasta, z jedne strony chca mieszkać w obszarach jak najbardziej uprzemystowionych, zapewniajacych przestrzenie potrzizedo codzinnego funkcjonowania, z drugiej chciałyby mieć stworzone optymalne warunki do egzystencii. Podażając za potrzebami mieszkańców, wiele miast daży do zapewnienia jak najlepszego komfortu zamieszkania poprzez wprowadzenie odpowiednich udogodnień jak np.: nowe tereny zieleni, ograniczenia $w$ emisji spalin i gazów czy minimalizacji strat cieplnych w budynkach. Dom ma stwarzać miejsce, w którym współczesny człowiek zregeneruje się. W dobie dzisiejszego pędu technologicznego, kiedy życie stawia wiele wyzwań wspótczesnemu człowiekowi to właśnie dom ma być ostoja wypoczynku i relaksu. Musi zatem maksymalizowac komfortowe warunki życia.

\section{Zadanie badawcze}

W artykule przedstawiona zostanie tylko część analizy wybranych czynnikow wpływających na komfort życi w wybranych obiektach mieszalnych, $w$ odniesieni do zapewnienia komfortu cieplnego. Badania zwiazzane z komfortem zamieszkania będą prowadzone przez kilka kolejnych lat. Uzyskane wyniki analiz i badań przyczynią się do wskazania najlepszych rozwiązań projektowo - budowlanych majacych na celu stworzenie dobrych warunkow zycia w obiektach mieszkalnych. Wnioski wy pdpowiednych rozwiazá projeztowych, któne w pizyszłości wpłyna na optymalizacie energochtonności budynku Odnio sie też do zagadnié́ stocowania zielen jako elementu zapewniajacego dobry mikroklimat oraz minimalizującego zanieczyszczenia powietrza.

Badania sa prowadzone w objektach wybudowanych w różnych okresach, w różnych technologiach $w$ różnych lokalizaciach. W niniejszym artykule przedstawiano tylko wybrane obiekty.

\section{Krótka charakterystyka przyrządów używanych do ba-}

dań poligonowych pomiarowe oraz informacje uzyskane od mieszkańców.
An important factor affecting the quality of life in today's world is the progres served and researched in almost all corners of the world. More and more often we hear about rising temperatures and the occurrence of unusual weather phenomena. Phenomena such as hurricanes, heavy rains or extreme temperatures are not beneficial for humans. Desertification caused by rising temperatures has also contributed to mass migration of people from agricultural areas to cities. The analyses conducted by the EEA ${ }^{6}$ or the IPCC 7 show that during the 21st century we will be confronted with number of weether a conles the will have a direct impect on our lives. The growh of poptio direct ies rest on (work in tron and living places), which loads to an increase in transport, problems with air pollution and the occurrence of the increasingly frequent observed effect of the Urban Heat Island ${ }^{8}$. In view of these changes, the essence of today's urban development and construction is the best possible protection of residents against possible threats related to climate change. Today's urban societies, on the one hand, want to live in the most industrialized areas, providing the spaces needed for everyday life, and on the other hand, want to have the optimal conditions for living. Following the needs of the inhabitants, many cities strive to provide the best possible comfort of living by introducing appropriate facilities, such as new green areas, limiting emissions of exhaust fumes and gase or minimizing heat losses in buildings. The house is should be a place where contemporary people will regenerate. In the era of today's technological momentum, and life poses many challenges to contemporary man, the house should be the mainstay of res and relaxation. Therefor the house must maximize the comfortable living conditions.

\section{Research task}

This article presents only a portion of the analysis of selected factors influencing the living comfort in chosen houses, in relation to the assurance of thermal comfort. Research related to the comfort of living will be conducted over the next few years. The results obtained by analyses and research will contribute to the identification of the best design and construction solution for the creation of good living conditions. Conclusions resulting from the research should be translated into the application of appropriate design solutions, whic in the future will affect the optimization of energy consumption of the building. They will also address the issue of using greenery as an element ensuring a good microclimate and minimizing air pollution.

Research will be carried out in houses built at different times, with different technologies and in different locations. In this article, only selected objects are presented.
Badania przeprowadzono za pomocą aparatury określajạcej zachowania przegrod zewnętrznych pod względem ochrony cieplnej budynku oraz stabilnej wilgotności przegrody.

$W$ badaniach użyto:

- skaner punktur rosy TROTEC BP 25 - ślad wiąski laserowej pozwala na zdalny pomiar temperatury na powierzchni przegrody, aktualnej temperatury i wilgotnosci otoczenia oraz podaje temperaturę, przy której może wystapić kondensacja pary wodnej na powierzchni przegrody, a co za tym idzie, może wystapić kondensacja pary wodnej, która doprowadzi do pleśni na powierzch ni przegrody.

TROTEC BM 22 - służący do pomiaru wilgotności powierzchniowej, zarówno w elementach drewnianych, ja i w elementach budynkow technologii tradycyjnej. pomira termowizyjna Seek Thermal - bezinwazyjny pomiar wraz z anizza wystecowania nostkow cieplnych mencie na przegrodzie. Zakres odczytywania temperatury przez kamerę to $-40^{\circ} \mathrm{C}-+330^{\circ} \mathrm{C}$.

\section{Ogólna charakterystyka budynków} okresach i wykonane w odmiennych technologiach. Z względu na materiały budowlane i konstrukcje pogrupowane zostały w dwie grupy: budynki wykonane $w$ technologii drewnianej oraz budynki wykonane $w$ technologii tradycyjnej.

Budynki w technologii drewnianej

Budynek nr 1. - wykonany w konstrukcji ściany wieńcowej z płazów drewnianych łączonych na zamek podhalański, ocieplony dodatkowo warstwą wełny mineralne od środka. Wybudowany w 2002 r. w Zakopanem. Budynek ogrzewany za pomocą pompy ciepla oraz czasowo płaszcza wodr zo ogrzewanego kominkiem.

Budynek $\mathrm{nr}$ 2. - wybudowany w technologii szkieletu drewnianego ocieplonego welną mineralną, wybudowany w latach 80-tych ubiegłego stulecia w Rucianym - Nidzie. Budynek ogrzewany grzejnikami elektrycznym jak też czasowo przez kominek i kuchnię węglową.

Budynki zlokalizowane w niewielkich miastach, znajdujących się w odmiennych obszarach klimatycznych, chrakteryzujących się dużą ilością terenów zielonych relatywnie niskim poziomem zaludnienia.

Budynki w technologii tradycyine

列 $10 \mathrm{~cm}$. wetny ming Przekryty stropodachem z płyt kanatowych ociewanych $5 \mathrm{~cm}$ styropianu oraz pokryty blacho - dachómka. Zostat wybudowany w latach 80 tych ubiegtego ste lecia, w jednym z zamknietych warszawskich osiedli mieszkaniowych Znajduje sie obszarze oddziatywania reki Wisty. Budynek zlokalizowany jest na prawym brzegu rzeki, w pasie napowietrzania stolicy zwiazanym z obszarem nadwiślańskim. Budynek ogrzewany piecem gazowym.

Budynek nr 4. - wybudowany w technologii tradycyjnej szkieletu żelbetowego wypełnionego pustakami ceramicznymi z bloczków betonowych, ocieplony wełn
Brief description of the instruments used for field tests During the on-ste inspection of the buildings, measurement data and information from residents were collected. The research was carried out with the use of equipment determining the behavior of externa building envelope in terms of thermal protection of the building and stable humidity.

In the research we used:

- TROTEC BP 25 dew point scanner - laser beam trace allows for remote measurement of temperature and humidity of the environment and gives the temperature at which condensation of water vapor may occur on the surface of the partition and thus condensation of water vapor may occur which will lead to mold on the surface of the wall.

-TROTEC BM 22 - used to measure surface moisture in both wooden and building elements in tradition technology

- Seek Thermal thermal imaging camera - non-invasive measurement together with analysis of thermbridges and anlysis of the temperature occuring given moment on the pertition. The temperature reading range of the camera is $-40^{\circ} \mathrm{C}-+330^{\circ} \mathrm{C}$

\section{General characteristics of buildings}

Buildings built in different periods of time and using different technologies were analyzed. Due to the construction materials and construction, they were dividdinto two groups: buildings made in wood technology and buildings made in traditional technology. Buildings in wooden technology

Building No. 1 - made in the structure of the corona wall made of wooden amphibians joined together with the "Podhale lock," insulated with mineral wool ayer from the inside, built in 2002 in Zakopane. The building is heated by a heat pump and temporarily by a water jacket heated by a fireplace.

Building No. 2 - built in the technology of a wooden skeleton insulated with mineral wool, built in the 1980 in Ruciane - Nida. The building is heated with electric heaters and temporarily by fireplace and coal kitchen Buildings are located in small towns, in different climatic areas, among large number of green areas and relatively low population.

Buildings in traditional technology

Building No. 3 - built in traditional brick technology from Sioprex aerated concrete brick, insulated with 10 $\mathrm{cm}$ mineral wool, covered with clinker bricks. Covered by a roof made of the hollow core slabs insulated $5 \mathrm{~cm}$ polystyrene and covered by steel roofing sheet. It was built in the 1980 's, in one of Warsaw's closed housing estate. Is located in the Vistula River impact area. The building is located on the right bank of the river in the aeration belt of the capital connected with the Vistula river area. The building is heated by a gas furnace. Building No. 4 - built in the traditional technology of reinforced concrete skeleton filled with ceramic blocks 
mineralną $20 \mathrm{~cm}$ i obłożono kamieniem - piaskowiec. Zlokalizowany został $\mathrm{w}$ jednej z podwarszawskich dzielzielonych, wybudowany w poblizu Rezerwatu Jana II Sobieskiego. Charakteryzuje się dużą ilością przeszkleń stanowiących jednocześnie otwarcia, jak i doświetlenie poszczególnych pomieszczeń. Budynek ogrzewany piecem gazowym.

Wszystkie domy są domami jednorodzinnymi, trzy z nich (budynki nr 1., nr 2. i $\mathrm{nr}$ 4.) są budynkami wolno stojącymi, budynek $\mathrm{nr} 3$. jest $\mathrm{w}$ zabudowie szeregowej Domy zlokalizowane w Warszawie znajduja się w kompleksach, przy których sa, relatywnie jak na duże miasto duże skupiska zieleni, które mają bezpośredni wpływ na poprawę komfortu zamieszkania. Przyczyniają się do pozanieczyszzzó oraz zmiejszania oddziatywania efektu Miejskiej Wyspy Ciepta -jszania oddzialywála efektu wadzonych przez Instytut Geografii i Przestzennego Zagospodarowania PAN, lokalizowanie obiektów mieszkalnych w poblizu dużych skupisk zieleni, wptywa korzystnie na poprawe lokalnie panujacych mikroklimatów. Zieleń, zwłaszcza wysoka, silnie oddziałuje na warunk termiczne i bioklimatyczne, co można w sposób skrótowy przedstawić następujaco:

- łagodzi warunki termiczne, zmniejszając tempo nagrzewania sie powietrza dniem $\mathrm{i}$ jego wychładzania noca - poprawia warunki wilgotnościowe, a obecność enklaw wilgoci poprawia warunki odczuwalne, ułatwia oddychanie i zmniejsza tempo wysuszania się skóry i bło śluzowych;

- generuje lokalną cyrkulację powietrza dzięki różnemu nagrzewaniu się powierzchni sztucznych i pokrytych roślinnością, co łagodzi warunki termiczne i ułatwia wnikanie strug powietrza pomiędzy zabudowę;

ułatwia oczyszczanie powietrza z zanieczyszczeń, zwłaszcza pyłowych, przez co poprawia komfort życia mieszkańców:

- poprawia warunki klimatu akustycznego, tłumiąc hałas generowany przez funkcjonowanie miasta.

Wyniki rozmów przeprowadzonych z mieszkańcam budynków

Podczas badań przeprowadzono rozmowy z mieszkańcami w celu głębszej analizy $w$ odniesieniu do zadowolenia z miejsca zamieszkania. W wyniku tych rozmów uzyskano następujące informacje:

istorian jest dobry, bardzo ra re ciepła, któ ra reg letnich dom sie nie przegrzewa, przez co Wokredogodne warunki do życia. Mieszkańcy zwrócili uwage na istotny aspekt bliskość terenów zieleni wpływajacych korzystnie na miejsce zamieszkania.

Budynek $\mathrm{nr}$ 2. - jak na obiekt funkcjonujacy już 40 la i wybudowany zgodnie $z$ ówcześnie obowiazzujacym normatywami wykazuje dość dobrą akumulacię cieplna Mieszkańcy podkreślili, iż w okresach zimowych, kiedy temperatura spada poniżej $-10^{\circ} \mathrm{C}$ wtedy odczuwaln jest pewien dyskomfort cieplny. Mieszkańcy nadmienili, iż w okresach zimowych wykorzystują węglową kuchnie of concrete, insulated with mineral wool $(20 \mathrm{~cm})$ and the suburban districts of Warsa age of green areas, built near the Jan III Sobieski Reserve. It is characterized by a large number of glazing which both open and illuminate the individual rooms. The building is heated by a gas furnace.

All houses are single-family houses, three of them (buildings No. 1, No. 2 and No. 4) are detached houses, building No. 3 is in terraced houses. Houses located in Warsaw are located in complexes with large green areas, which have a direct impact on improving the comfort of living. They contribute to the improvement of external conditions, in particular to the reduction of pollution and the impact of the Urban Heat Island effect. According to the research ducted by the Institute of Geography and Spationvelopment of the Polish Academy of Sciences, loeting residential buildings in the vicinity of large locatzones has a positive impact on the improve green locel microclimates. Green areas, especially high greenery, strongly infuences thers, end biocligh greenditions, which can be sum

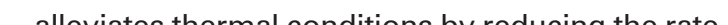

which the air heats up and cools down at night;

-improves humidiv condilos and the prisen

improves humidty and condions and the presence dition, faciling bre which skin and mucous Which skin and mucous membranes dry out;

- generates local air circulation due to the different heating of articial and vegetation surfaces, which mitigates thermal conditions and fachltates the pentration of air streams between buildings;

- makes it easier to clean the air of pollutants, especially dust, thus improving the quality of life of the residents, improves acoustic climate conditions, suppressing oise generated by the functioning of the city.

Results of interviews conducted with residents of buildings

During the research, interviews with residents were conducted in order to analyze more deeply the satisfaction with their place of living. As a result of these interviews, the following information was obtained: Building no. 1 - The comfort of living is good, the heat pump plays a very important role here, whic egulates the heating in winter. In summer, the house does not overheat, which creates favorable living conditions. Residents drew attention to an important aspect of the proximity of green areas that have a positive impact on the place of residence. Building No. 2 - Considering that this building has been in operation for 40 years and built in accordance with the regulatory standards of that time, it shows a fairly good thermal accumulation. Residents emphasized that in winter, when the temperature drops below $-10^{\circ} \mathrm{C}$, a certain thermal discomfort is elt. Residents mentioned, that in winter, they use the kaflową do dogrzania domu, gdyż poprawia ona komfort cieplny o kilka stopni.

Budynek nr 3. - podobnie jak budynek nr 2. jest zamieszkały od ponad 30 lat, niestety w okresach zimowych, kiedy temperatury spadają poniżej $-10^{\circ} \mathrm{C}$ dom wychładza sie oraz bardzo nagrzewa w okresach letnich, kiedy panuja upały powyzej jo C. Stwarza to niekorzystne warunki dla mieszkanców. Jak podkreslają dom nie został odpowiednio zabezpieczony przeciwko przegrzewaniu i wychładzaniu. Zlokalizowanie budynku w pobliżu rzeki i terenów zieleni stanowi istotny element komfortu zamieszkania dla mieszkancow. Mały przydomowy ogródek przyczy nia sie do poprawy warunków mikroklimatycznych życia. Jednocześnie podkrestili, iz̀ sama lokalizacja $6 \mathrm{~km}$. od centrum Warszawy jest bardzo istotna dla nich w odnie-
sieniu do zagadnienia transportu.

Budýek 4. - mieszkancy domu są zadowoleni z waatem, jak i zima zapewniony jest komfort cieplny w budynku. Jedyna zmiana wprowadzona prze użyt kowników w 2018 r. było zainstalowanie urzadzenia do oczyszczania powietrza w zwiazku z pogarszajacym sie stanem powietrza w okolicy. Ponieważ budynek zlokalizowany jest $w$ jednej z podmiejskich dzielnicy Warszawy, dla nich z kolei uciażliwościa jest dojazd do pracy, niejednokrotnie w godzinach szczytu wiazze sie to z podróża w korkach, w zanieczyszczonym spalinami powietrzu.

Wyniki badań poszczególnych budynków

Budynek nr 1.

Pomiary badawcze wykonane w wybranych punktach Pudynku wewnattz i na zewnatrz $w$ dniu 16 listopada 2018 r. i 17 lipca 2018 r. w godzinach $10^{00}-11^{00}$

\section{za pomocą urządzania TROTEC BP25}

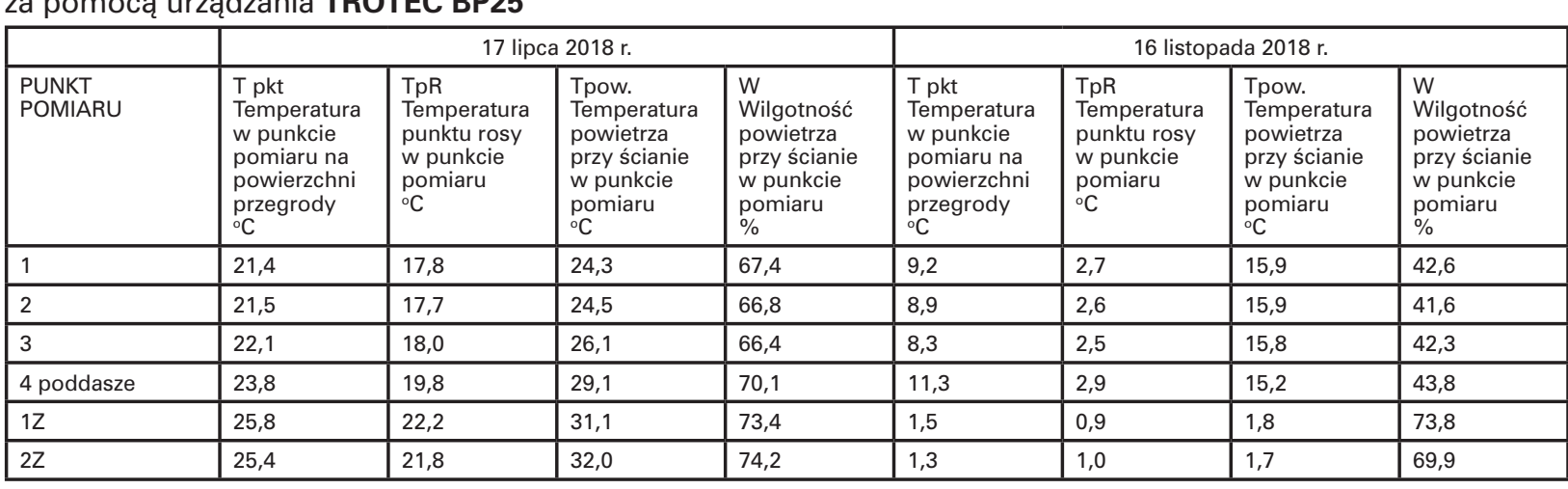

with the use of TROTEC BP25 device.

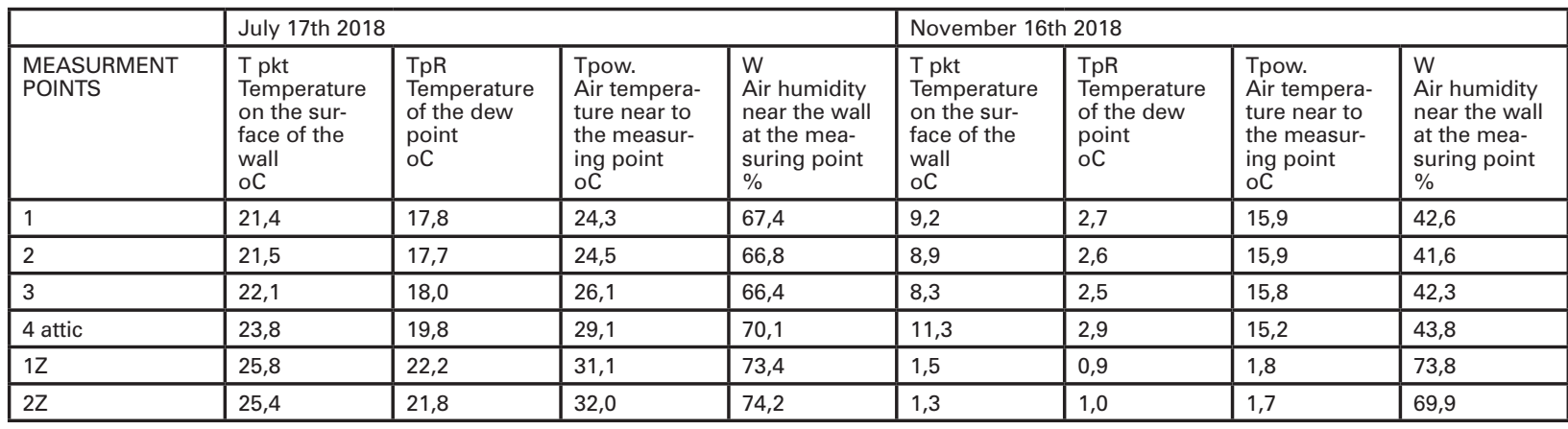

coal tile kitchen to heat up the house, because it im-

Building No. 3 - Similar to building No. 2. has been down and it is very warm in summer when the hea is above $30^{\circ} \mathrm{C}$. This creates unfavorable conditions for protected against overheating and cooling. Location of the building near the river and green areas is an important element of the comfort of living for the residents. A small backyard garden contributes to the improvement of microclimate living conditions. At the same time, they stressed that the location itself is far from the center of Warsaw $(6 \mathrm{~km})$. This is very important for

Building 4 - The residents of this house are satisfied with the conditions and climate of the building. Thermal comfort in the building is ensured both in the summer and winter. The only change introduced by the users in 2018 was the installation of an air purification unit due to the deteriorating air condition in the area. Since the building is located in one of the Sin anis hours, involves travel in traffic jams with polluted air.

\section{Test results of individual buildings.}

\section{Building no. 1}

measurements made in selected points of he building inside and outside on November $16^{\prime \prime}$ 2018 and July $17^{\text {th }} 2018$ from $10^{00}$ to $11^{00}$ proves thermal comfort by several degrees. inhabited for over 30 years. Unfortunately in winter, the residents in relation to the issue of transport. 
za pomocą urządzania TROTEC BM22

\begin{tabular}{|l|l|l|}
\hline & \multicolumn{1}{|c|}{17 lipca 2018 r. } & 16 listopada 2018 r. \\
\hline $\begin{array}{l}\text { PUNKT } \\
\text { POMIARU }\end{array}$ & $\begin{array}{l}\text { W } \\
\text { Wilgotność ściany } \\
\%\end{array}$ & $\begin{array}{l}\text { W } \\
\text { Wilgotność ściany } \\
\%\end{array}$ \\
\hline 1 & 11 & 13 \\
\hline 2 & 10 & 12 \\
\hline 3 & 10 & 12 \\
\hline 4 poddasze & 9 & 10 \\
\hline $1 Z$ & 14 & 17 \\
\hline $4 Z$ & 14 & 15 \\
\hline
\end{tabular}

with the use of TROTEC BM22 device.

\begin{tabular}{|l|l|l|}
\hline & \multicolumn{1}{|c|}{ July $17^{\text {th }} 2018$} & November $16^{\text {th } 2018}$ \\
\hline $\begin{array}{l}\text { MEASURMENT } \\
\text { POINTS }\end{array}$ & $\begin{array}{l}\text { W } \\
\text { Wall humidity } \\
\%\end{array}$ & $\begin{array}{l}\text { W } \\
\text { Wall humidity } \\
\%\end{array}$ \\
\hline 1 & 11 & 13 \\
\hline 2 & 10 & 12 \\
\hline 3 & 10 & 12 \\
\hline 4 attic & 9 & 10 \\
\hline $1 Z$ & 14 & 17 \\
\hline $4 Z$ & 14 & 15 \\
\hline
\end{tabular}

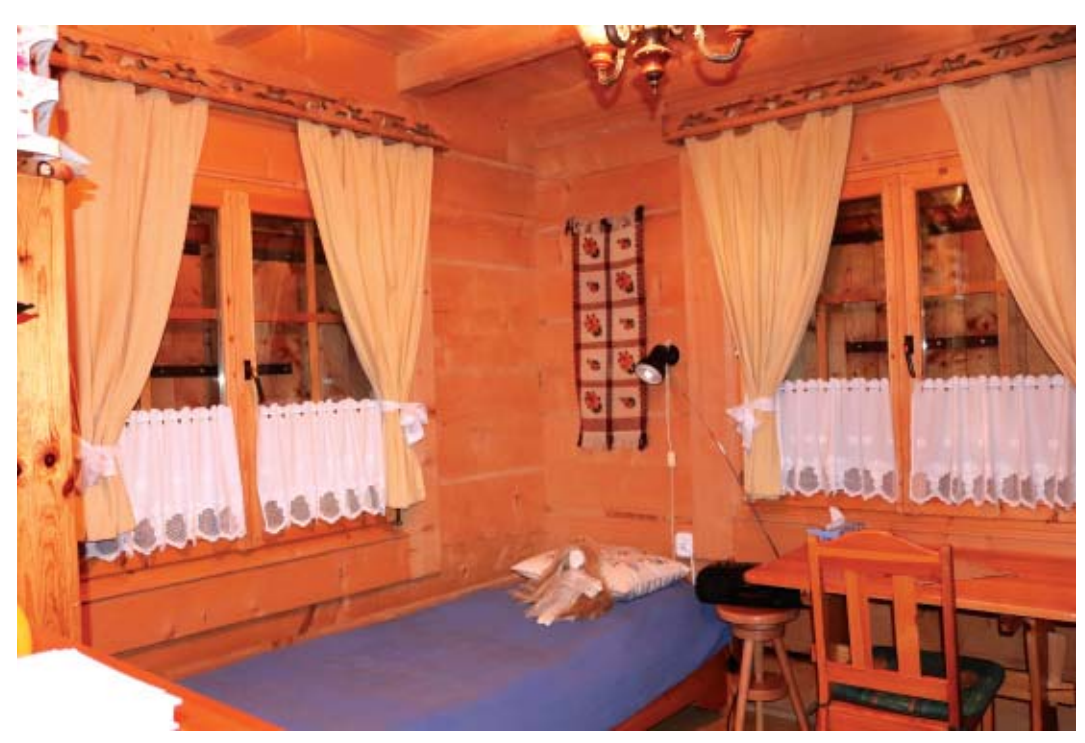

II. 1. jedno $\mathbf{z}$ pomieszczeń $\mathbf{w}$ budynku nr 1 - sypialnia na parterze, wschodnio - potudniowe naroże domu, fot. J. Klimowicz / one of the rooms in building no 1 - bedroom on the ground floor, east - south corner of the house, Photo J. Klimowicz
II. 2. kamera termowizyja 16 listopada 2018 r., fot. J. Klimowicz/ thermal camera November $16^{\mathrm{t}} 2018$, photo. J. Klimowicz

Badanie kamerą termowizyjną Seek Thermal przeprowadzone były we wszystkich punktach pomiarowych, poniżej przykład jednego punktu pomiarowego $z$ dnia 16 liwynik pomiaru kamerą termowizyjną w punkcie 2)

\section{Budynek nr 2.}

Pomiary badawcze wykonane $\mathbf{w}$ wybranych punktach budynku wewnątrz i na zewnątrz w dniu 15 lipca 2018 r. i 17 listopada $2018 \mathrm{r}$. w godzinach $10^{00}-110^{00}$

The tests made by The Seek Thermal thermal imaging presented the example of one mesuing point on November $16^{\text {th }} 2018$. (photo of the building $n 0.1$ and the

Building no. 2.

Research measurements made in selected points of the building inside and outside on July $15^{\text {th }} 2018$ and ovember $17^{\text {th }} 2018$ from $10^{00}$ to $11^{100}$

\begin{tabular}{|c|c|c|c|c|c|c|c|c|}
\hline \multirow[b]{2}{*}{$\begin{array}{l}\text { PUNKT } \\
\text { POMIARU }\end{array}$} & \multicolumn{4}{|c|}{15 lipca 2018 r. } & \multicolumn{4}{|c|}{17 listopada 2018 r. } \\
\hline & $\begin{array}{l}\text { Tpkt } \\
\text { Temperatura } \\
\text { w punkkie } \\
\text { pomiaru na } \\
\text { powierzchni } \\
\text { przegrody } \\
\text { oc }\end{array}$ & $\begin{array}{l}\text { TpR } \\
\text { Temperatura } \\
\text { punktu rosy } \\
\text { w punkcie } \\
\text { pomiaru } \\
\text { oc }\end{array}$ & \begin{tabular}{|l|} 
Tpow. \\
Temperatura \\
powietrza \\
prry scianie \\
w punkcie \\
pomiaru \\
oc
\end{tabular} & $\begin{array}{l}\text { W } \\
\text { Wilgotność } \\
\text { powietrza } \\
\text { przy śianie } \\
\text { w punkcie } \\
\text { pomiaru } \\
\%\end{array}$ & \begin{tabular}{|l|} 
Tpkt \\
Temperatura \\
w punkcie \\
pomiaru na \\
powiercchni \\
przegrody \\
oc
\end{tabular} & $\begin{array}{l}\text { TpR } \\
\text { Temperatura } \\
\text { punktu rosy } \\
\text { w punkcie } \\
\text { pomiaru } \\
\text { oc }\end{array}$ & $\begin{array}{l}\text { Tpow. } \\
\text { Temperatura } \\
\text { powietrza } \\
\text { prry śianie } \\
\text { w punkkie } \\
\text { pomiaru } \\
\text { oc }\end{array}$ & \begin{tabular}{|l} 
W \\
Wilgotnośá \\
powietrza \\
przy ściani \\
w punkcie \\
pomiaru \\
$\%$
\end{tabular} \\
\hline 1 & 21,6 & 16,8 & 25,3 & 66,4 & 14,6 & 1,9 & 14,9 & 41,4 \\
\hline 2 & 22,1 & 17,1 & 26,4 & 65,3 & 13,4 & 15,2 & 13,2 & 46,2 \\
\hline 3 poddasze & 24,8 & 18,4 & 29,8 & 69,1 & 18,1 & 3,9 & 17,3 & 42,7 \\
\hline 4 poddasze & 25,8 & 18,3 & 29,8 & 68,4 & 17,0 & 3,7 & 17,0 & 40,5 \\
\hline 1 Z ganek & 25,4 & 17,2 & 28,3 & 67,2 & 12,4 & 3,4 & 13,8 & 48,2 \\
\hline 22 & 27,1 & 22,1 & 31,8 & 72,3 & 0,9 & 0,5 & 1,1 & 71,2 \\
\hline
\end{tabular}

with the use of TROTEC BP25 device.

\begin{tabular}{|c|c|c|c|c|c|c|c|c|}
\hline \multirow[b]{2}{*}{$\begin{array}{l}\text { MEASURMENT } \\
\text { POINTS }\end{array}$} & \multicolumn{4}{|l|}{ July 15th 2018} & \multicolumn{4}{|c|}{ November 17th 2018} \\
\hline & $\begin{array}{l}\text { Tpkt } \\
\text { Temperature } \\
\text { on the sur- } \\
\text { face of the } \\
\text { wall } \\
\text { oC }\end{array}$ & \begin{tabular}{|l|} 
TpR \\
Temperature \\
of the dew \\
point \\
oC \\
\end{tabular} & \begin{tabular}{|l|} 
Tpow. \\
Air tempera- \\
ture near to \\
the measur- \\
ing point \\
oC \\
\end{tabular} & $\begin{array}{l}\text { W } \\
\text { Air humidity } \\
\text { near the wall } \\
\text { at the mea- } \\
\text { suring point } \\
\%\end{array}$ & \begin{tabular}{|l|} 
Tpkt \\
Temperature \\
on the sur- \\
face of the \\
wall \\
oC
\end{tabular} & \begin{tabular}{|l|}
$T p R$ \\
Temperature \\
of the dew \\
point \\
oC
\end{tabular} & $\begin{array}{l}\text { Tpow. } \\
\text { Air tempera- } \\
\text { ture near to } \\
\text { the measur- } \\
\text { ing point } \\
\text { oC } \\
\end{array}$ & $\begin{array}{l}\text { W } \\
\text { Air humiditiv } \\
\text { nearar the wall } \\
\text { at the mea- } \\
\text { suring point } \\
\%\end{array}$ \\
\hline 1 & \begin{tabular}{|l|l|}
21,6 \\
\end{tabular} & 16,8 & 25,3 & 66,4 & \begin{tabular}{|l|}
14,6 \\
\end{tabular} & 1,9 & 14,9 & 41,4 \\
\hline 2 & 22,1 & 17,1 & 26,4 & 65,3 & 13,4 & 15,2 & 13,2 & 46,2 \\
\hline 3 attic & 24,8 & 18,4 & 29,8 & 69,1 & 18,1 & 3,9 & 17,3 & 42,7 \\
\hline 4 attic & 25,8 & 18,3 & 29,8 & 68,4 & 17,0 & 3,7 & 17,0 & 40,5 \\
\hline $1 \mathrm{z}$ porch & 25,4 & 17,2 & 28,3 & 67,2 & 12,4 & 3,4 & 13,8 & 48,2 \\
\hline 22 & 27,1 & 22,1 & 31,8 & 72,3 & 0,9 & 0,5 & 1,1 & 71,2 \\
\hline
\end{tabular}

za pomocą urządzania TROTEC BM22

\begin{tabular}{|l|l|l|}
\hline \multicolumn{1}{|c|}{15 lipca 2018 r. } & \multicolumn{1}{c|}{17 listopada 2018 r. } \\
\hline $\begin{array}{l}\text { PUNKT } \\
\text { POMIARU }\end{array}$ & $\begin{array}{l}\text { W } \\
\text { Wilgotnośćściany } \\
\%\end{array}$ & $\begin{array}{l}\text { Wilgotnośćsciany } \\
\%\end{array}$ \\
\hline 1 & 10 & 12 \\
\hline 2 & 11 & 13 \\
\hline 3 poddasze & 8 & 10 \\
\hline 4 poddazze & 11 & 10 \\
\hline $1 Z$ ganek & 12 & 14 \\
\hline $2 Z$ & 13 & 16 \\
\hline
\end{tabular}

with the use of TROTEC BM22 device.

\begin{tabular}{|l|l|l|}
\hline & July 15th 2018 & November 17th 2018 \\
\hline $\begin{array}{l}\text { MEASURMENT } \\
\text { POINTS }\end{array}$ & $\begin{array}{l}\text { W } \\
\text { Wall humidity } \\
\%\end{array}$ & $\begin{array}{l}\text { W } \\
\text { Wall humidity } \\
\%\end{array}$ \\
\hline 1 & 10 & 12 \\
\hline 2 & 11 & 13 \\
\hline 3 attic & 8 & 10 \\
\hline 4 attic & 11 & 10 \\
\hline $1 Z$ porch & 12 & 14 \\
\hline $2 Z$ & 13 & 16 \\
\hline
\end{tabular}

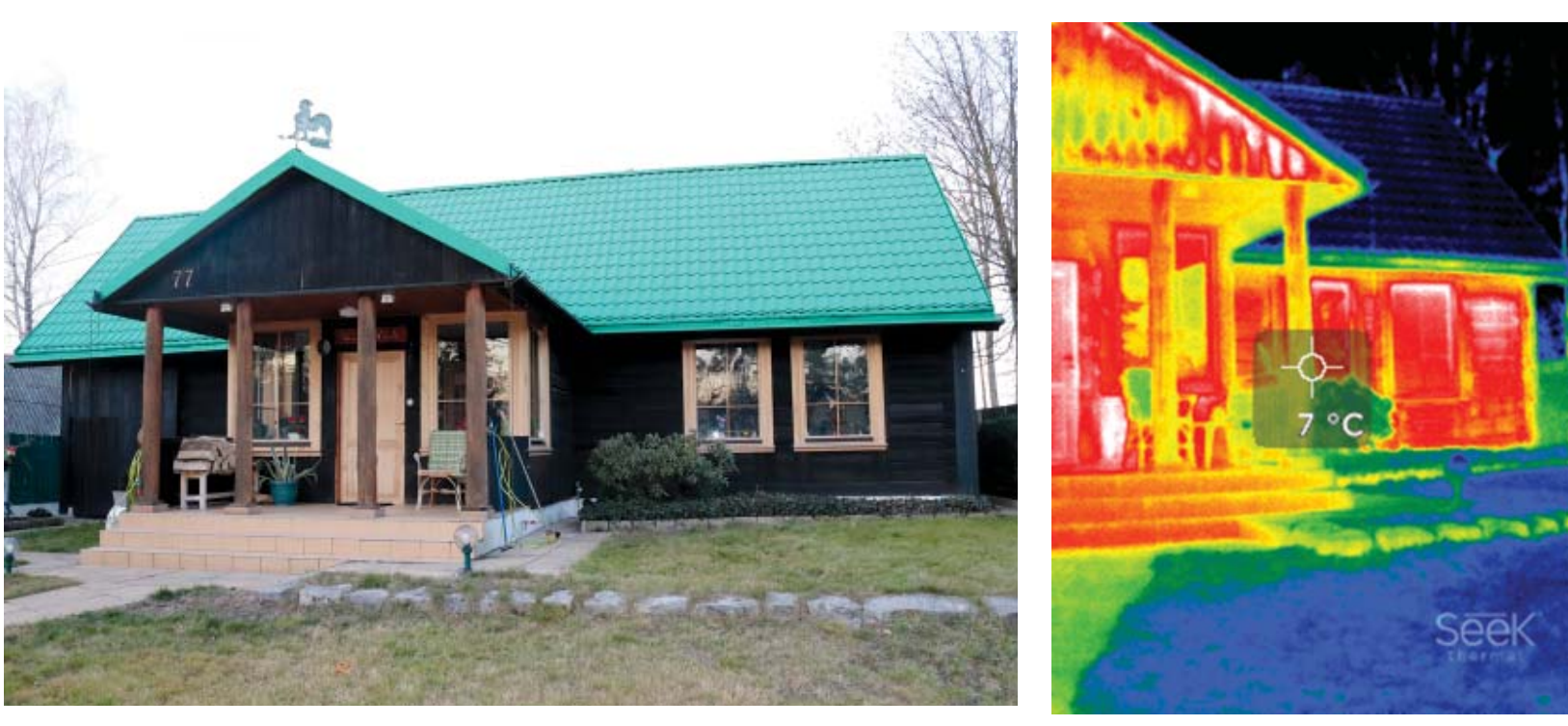

II. 3. elewacja frontowa, potudniowa budynku nr 2, fot. J. Klimowicz $/$ Photo 2 -south front elevation of the building no 2, photo, J. Klimow

Badanie kamerą termowizyjną Seek Thermal przeprowadzone były we wszystkich punktach pomiarowych, poniżej przykład jednego punktu pomiarowego z dnia 17 listopada 2018 r. (zdjecie badanego budynku nr 2 oraz wynik pomiaru kamera termowizyjną w punkcie $2 \mathrm{Z}$ )

\section{Budynek nr 3.}

Pomiary badawcze wykonane $\mathbf{w}$ wybranych punktach budynku wewnątrz i na zewnątrz w dniu 12 marca 2019 r. i 15 czerwca 2019 r. w godzinach $10^{00}-11^{00}$
The tests made by The Seek Thermal thermal imaging camera was carried out at all measuring points, below is presented the example of one measuring point on November 17 $17^{\text {th }}$ 2018. (photo of the building no. 2 and the result of the thermal camera measurement in point 2Z) Building no. 3.

Research measurements made in selected points of and June $15^{\text {th }} 2019$ from $10^{00}$ to $11^{00}$ the building inside and outside on March $12^{\text {th }} 2019$ 
za pomocą urządzania TROTEC BP25

\begin{tabular}{|c|c|c|c|c|c|c|c|c|}
\hline & \multicolumn{4}{|c|}{12 marca $2019 \mathrm{r}}$. & \multicolumn{4}{|c|}{15 czerwca 2019 r. } \\
\hline $\begin{array}{l}\text { PUNKT } \\
\text { POMIARU }\end{array}$ & $\begin{array}{l}\text { T pkt } \\
\text { Temperatura } \\
\text { w punckie } \\
\text { pomiaru na } \\
\text { powierzchni } \\
\text { przegrody } \\
\text { oc }\end{array}$ & $\begin{array}{l}\text { TpR } \\
\text { Temperatura } \\
\text { punktu rosy } \\
\text { w punkcie } \\
\text { pomiaru } \\
\text { oC }\end{array}$ & $\begin{array}{l}\text { Tpow. } \\
\text { Temperatura } \\
\text { powietraz } \\
\text { przy scianie } \\
\text { w punkcie } \\
\text { pomiaru } \\
{ }^{\circ} \mathrm{C}\end{array}$ & $\begin{array}{l}\text { W } \\
\text { Wilgotność } \\
\text { powietrza } \\
\text { przy śianie } \\
\text { w punkcie } \\
\text { pomiaru } \\
\%\end{array}$ & $\begin{array}{l}\text { T pkt } \\
\text { Temperatura } \\
\text { w punckie } \\
\text { pomiaru na } \\
\text { powierzchni } \\
\text { przegrody } \\
{ }^{\circ} \mathrm{C}\end{array}$ & $\begin{array}{l}\text { TpR } \\
\text { Temperatura } \\
\text { punktu rosy } \\
\text { w punkcie } \\
\text { pomiaru } \\
\text { 'C }\end{array}$ & $\begin{array}{l}\text { Tpow. } \\
\text { Tomperatura } \\
\text { powietrza } \\
\text { przy ścianie } \\
\text { w punkcie } \\
\text { pomiaru } \\
\text { oc }\end{array}$ & $\begin{array}{l}\text { W } \\
\text { Wilgotnośćc } \\
\text { powietrza } \\
\text { prry śianie } \\
\text { w punkcie } \\
\text { pomiaru } \\
\%\end{array}$ \\
\hline 1 & 18,7 & 15,5 & 20,3 & 71,4 & 26,2 & 22,1 & 29,1 & 69,1 \\
\hline 2 & 17,9 & 15,9 & 20,4 & 72,3 & 26,4 & 22,2 & 29.1 & 68,9 \\
\hline 3 & 17,9 & 15,3 & 20,5 & 70,4 & 26,8 & 21,9 & 29,5 & 68,4 \\
\hline $1 \mathrm{Z}$ & 11,2 & 10,2 & 13,8 & 69,1 & 29,8 & 24,5 & 30,0 & 67,1 \\
\hline & & 10,3 & 13,4 & 68,9 & 29,8 & 23,8 & 30,5 & 66,9 \\
\hline
\end{tabular}

with the use of TROTEC BP25 device.

\begin{tabular}{|c|c|c|c|c|c|c|c|c|}
\hline \multirow[b]{2}{*}{$\begin{array}{l}\text { MEASURMENT } \\
\text { POINTS }\end{array}$} & \multicolumn{4}{|l|}{ March 12th 2019} & \multicolumn{4}{|c|}{ June 15th 2019} \\
\hline & \begin{tabular}{|l} 
Tpkt \\
Temperature on \\
the surface of the \\
wall \\
oc
\end{tabular} & $\begin{array}{l}\text { TpR } \\
\text { Temperature } \\
\text { of the dew } \\
\text { point } \\
{ }^{\circ} \text { C }\end{array}$ & $\begin{array}{l}\text { Tpow. } \\
\text { Ait tempera- } \\
\text { ture near to } \\
\text { the measur- } \\
\text { ing point } \\
\text { oC }\end{array}$ & $\begin{array}{l}\text { W } \\
\text { Air humid- } \\
\text { ity near the } \\
\text { wall at the } \\
\text { measuring } \\
\text { point } \\
\%\end{array}$ & $\begin{array}{l}\text { T pkt } \\
\text { Temperature } \\
\text { on the sur- } \\
\text { face of the } \\
\text { wall } \\
\text { oC }\end{array}$ & \begin{tabular}{|l|} 
TpR \\
Temperature \\
of the dew \\
point \\
oc
\end{tabular} & \begin{tabular}{|l} 
Tpow. \\
Airtempera- \\
ture near to \\
the measur- \\
ing point \\
oc
\end{tabular} & \begin{tabular}{|l} 
W \\
Air humid- \\
ity near the \\
wall at the \\
measuring \\
point \\
$\%$
\end{tabular} \\
\hline 1 & 18,7 & 15,5 & 20,3 & 71,4 & 26,2 & 22,1 & 29,1 & 69,1 \\
\hline 2 & 17,9 & 15,9 & 20,4 & 72,3 & 26,4 & 22,2 & 29.1 & 68,9 \\
\hline 3 & 17,9 & 15,3 & 20,5 & 70,4 & 26,8 & 21,9 & 29,5 & 68,4 \\
\hline 12 & 11,2 & 10,2 & 13,8 & 69,1 & 29,8 & 24,5 & 30,0 & 67,1 \\
\hline $2 z$ & 11,5 & 10,3 & 13,4 & 68,9 & 29,8 & 23,8 & 30,5 & 66,9 \\
\hline
\end{tabular}

za pomocą urządzania TROTEC BM22
\begin{tabular}{|l|l|l|}
\hline \multicolumn{1}{|c|}{12 marca 2019 r. } & \multicolumn{1}{|c|}{15 czerwca 2019 r. } \\
\hline $\begin{array}{l}\text { PUNKT } \\
\text { POMIARU }\end{array}$ & $\begin{array}{l}\text { W } \\
\text { Wilgotność ściany } \\
\%\end{array}$ & $\begin{array}{l}\text { W } \\
\text { Wilgotnośćściany } \\
\%\end{array}$ \\
\hline 1 & 0,8 & 0,6 \\
\hline 2 & 0,8 & 0,5 \\
\hline 3 & 0,8 & 0,5 \\
\hline $1 Z$ & 0,8 & 0,6 \\
\hline $2 Z$ & 0,7 & 0,5 \\
\hline
\end{tabular}

with the use of TROTEC BM22 device.

\begin{tabular}{|l|l|l|}
\hline & March 12th 2019 & June 15th 2019 \\
\hline $\begin{array}{l}\text { MEASURMENT } \\
\text { PEINTS }\end{array}$ & $\begin{array}{l}\text { W } \\
\text { Wall humidity } \\
\%\end{array}$ & $\begin{array}{l}\text { W } \\
\text { Wall humidity } \\
\%\end{array}$ \\
\hline 1 & 0,8 & 0,6 \\
\hline 2 & 0,8 & 0,5 \\
\hline 3 & 0,8 & 0,5 \\
\hline $1 Z$ & 0,8 & 0,6 \\
\hline $2 Z$ & 0,7 & 0,5 \\
\hline
\end{tabular}

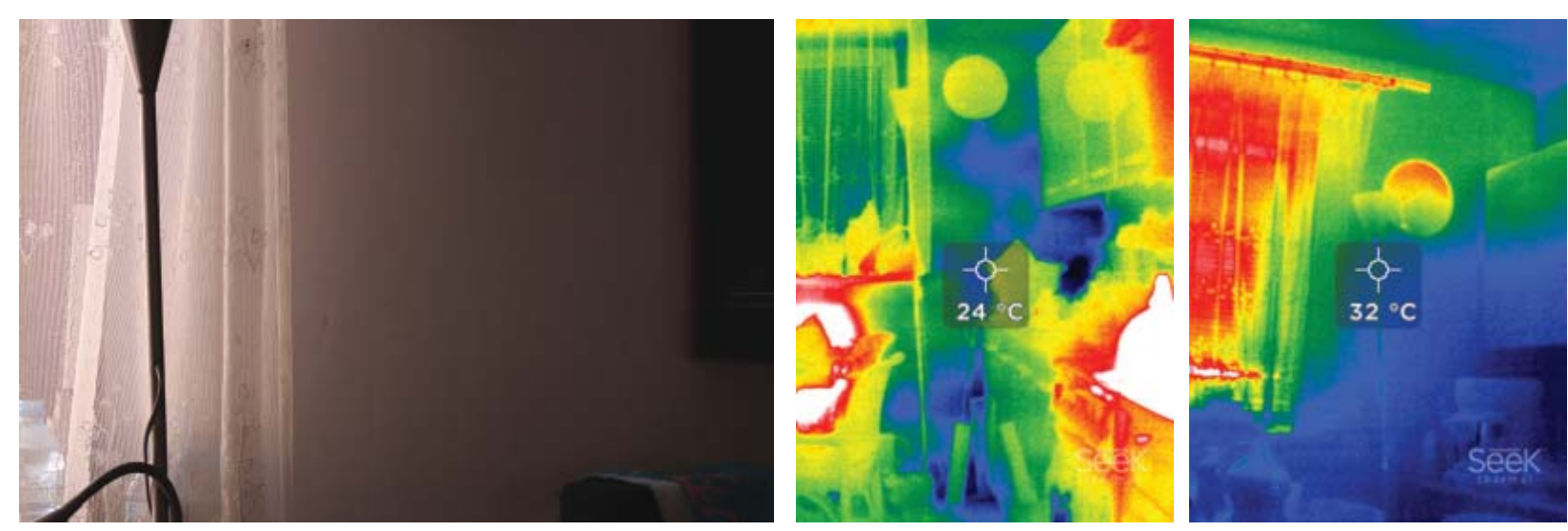

II. 5. fragment wnetrza budynku nr 3 kuchnia. połączenie ściany zewnętrznej ze ścianą od sąsiada, fot. J. Klimowicz / interior of building no 3

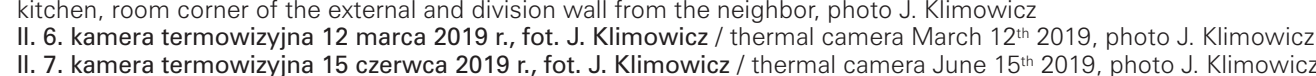

Badanie kamerą termowizyjną Seek Thermal przeprowadzone były we wszystkich punktach pomiarowych, ponizej przyklad jednego punku pomiarowego z dnia 12 marca i 15 czerwca 2019 r. (zdjęcie badanego budynku nr 3 oraz wynik pomiaru kamerą termowizyjna w punkcie 2)

\section{Budynek nr 4.}

wybranych punktac budynku wewnątrz i na zewnątrz $\mathrm{W}$ dniu 10 kwietn 2019 r. i 12 czerwca 2019 r.

The tests made by The Seek Thermal thermal imaging camera wa below is presented the example of one measuring point on March $12 \mathrm{~d}$ and June $15 \mathrm{~m} 2019$. (photo of the measurement in point 2)

\section{Building no. 4.}

Research measurements made in selected points of the building inside and outside on April $10^{\text {th }} 2019$ and June $12^{\text {th }} 2019$ from $9^{00}$ to $10^{00}$

a pomocą urządzania TROTEC BP25

\begin{tabular}{|c|c|c|c|c|c|c|c|c|}
\hline & \multicolumn{4}{|c|}{10 kwietnia 2019 r. } & \multicolumn{4}{|c|}{12 czerwca 2019 r. } \\
\hline $\begin{array}{l}\text { PUNKT } \\
\text { POMIARU }\end{array}$ & $\begin{array}{l}\text { T pkt } \\
\text { Temperatura } \\
\text { w punkcie } \\
\text { pomiaru na } \\
\text { powierzchni } \\
\text { przegrody } \\
{ }^{\circ} \mathrm{C}\end{array}$ & $\begin{array}{l}\text { TpR } \\
\text { Temperatura } \\
\text { punktur rosy } \\
\text { w punkcie } \\
\text { pomiaru } \\
{ }^{\circ} \mathrm{C}\end{array}$ & $\begin{array}{l}\text { Tpow. } \\
\text { Temperatura } \\
\text { powietrza } \\
\text { przy ścianie } \\
\text { w punkcie } \\
\text { pomiaru } \\
\text { oc }\end{array}$ & $\begin{array}{l}\text { W } \\
\text { Wilgotność } \\
\text { powietrza } \\
\text { prry ścianie } \\
\text { w punkcie } \\
\text { pomiaru } \\
\%\end{array}$ & $\begin{array}{l}\text { Tpkt } \\
\text { Temperatura } \\
\text { w punkcie } \\
\text { pomiaru na } \\
\text { powierzchni } \\
\text { przegrody } \\
\text { oc }\end{array}$ & $\begin{array}{l}\text { TpR } \\
\text { Temperatura } \\
\text { punktu rosy } \\
\text { w punckie } \\
\text { pomiarcu } \\
\text { oc }\end{array}$ & \begin{tabular}{|l|} 
Tpow. \\
Temperatura \\
powietrza \\
prry scianie \\
w punkeie \\
pomiaru \\
occ
\end{tabular} & $\begin{array}{l}\text { W } \\
\text { Wilgotnośććc } \\
\text { powietrza } \\
\text { przy ścianie } \\
\text { w punkcie } \\
\text { pomiaru } \\
\% \\
\%\end{array}$ \\
\hline 1 & 18,7 & 15,5 & 20,3 & 71,4 & 26,2 & 22,1 & 29,1 & 69,1 \\
\hline 2 & 18,3 & 15,7 & 20,5 & 72,8 & 26,3 & 22,4 & 29,6 & 68,1 \\
\hline 3 & 18,2 & 16,1 & 20,6 & 71,4 & 25,7 & 21,8 & 29,4 & 68,6 \\
\hline 12 & 11,2 & 10,2 & 13,8 & 69,1 & 29,8 & 24,5 & 30,0 & 67,1 \\
\hline $2 z$ & 11,4 & 10,2 & 13,1 & 68,1 & 29,5 & 24,3 & 30,5 & 66,1 \\
\hline $3 z$ & 10,9 & 9,8 & 12,9 & 68,6 & 29,7 & 23,7 & 30,2 & 66,2 \\
\hline
\end{tabular}

with the use of TROTEC BP25 device.

\begin{tabular}{|c|c|c|c|c|c|c|c|c|}
\hline & \multicolumn{4}{|c|}{ April 10th 2019} & \multicolumn{4}{|c|}{ June 12th 2019} \\
\hline $\begin{array}{l}\text { MEASURMENT } \\
\text { POINTS }\end{array}$ & $\begin{array}{l}\text { T pkt } \\
\text { Temperature } \\
\text { on the sur- } \\
\text { face of the } \\
\text { wall } \\
{ }^{\circ C}\end{array}$ & \begin{tabular}{|l} 
TpR \\
Temperature \\
of the dew \\
point \\
${ }^{\circ} \mathrm{C}$
\end{tabular} & $\begin{array}{l}\text { Tpow. } \\
\text { Air tempera- } \\
\text { ture near to } \\
\text { the measur- } \\
\text { ing point } \\
{ }^{\circ} \mathrm{C}\end{array}$ & $\begin{array}{l}\text { W } \\
\text { Air humidity } \\
\text { near the wall } \\
\text { at the maa- } \\
\text { suring point } \\
\%\end{array}$ & $\begin{array}{l}\text { T pkt } \\
\text { Temperature } \\
\text { on the sur- } \\
\text { face of the } \\
\text { wall } \\
{ }^{\circ} \mathrm{C}\end{array}$ & $\begin{array}{l}\text { TpR } \\
\text { Temperature } \\
\text { of the dew } \\
\text { point } \\
{ }^{\circ} \mathrm{C}\end{array}$ & $\begin{array}{l}\text { Tpow. } \\
\text { Air tempera- } \\
\text { ture near to } \\
\text { the measur- } \\
\text { ing point } \\
{ }^{\circ} \mathrm{C}\end{array}$ & $\begin{array}{l}\text { W } \\
\text { Air humidity } \\
\text { near the wall } \\
\text { at the mea- } \\
\text { suring point } \\
\%\end{array}$ \\
\hline 1 & 18,7 & 15,5 & 20,3 & 71,4 & 26,2 & 22,1 & 29,1 & 69,1 \\
\hline 2 & 18,3 & 15,7 & 20,5 & 72,8 & 26,3 & 22,4 & 29,6 & 68,1 \\
\hline 3 & 18,2 & 16,1 & 20,6 & 71,4 & 25,7 & 21,8 & 29,4 & 68,6 \\
\hline 12 & 11,2 & 10,2 & 13,8 & 69,1 & 29,8 & 24,5 & 30,0 & 67,1 \\
\hline 22 & 11,4 & 10,2 & 13,1 & 68,1 & 29,5 & 24,3 & 30,5 & 66,1 \\
\hline $3 Z$ & 10,9 & 9,8 & 12,9 & 68,6 & 29,7 & |23,7 & | 30,2 & 66,2 \\
\hline
\end{tabular}

za pomocą urządzania TROTEC BM22

\begin{tabular}{|l|l|l|}
\hline \multicolumn{1}{|c|}{10 kwietnia 2019 r. } & \multicolumn{1}{c|}{12 czerwca 2019 r. } \\
\hline $\begin{array}{l}\text { PUNKT } \\
\text { POMIARU }\end{array}$ & $\begin{array}{l}\text { W } \\
\text { Wilgotnośćściany } \\
\%\end{array}$ & $\begin{array}{l}\text { W } \\
\text { Wigotność ściany } \\
\%\end{array}$ \\
\hline 1 & 0,7 & 0,4 \\
\hline 2 & 0,7 & 0,4 \\
\hline 3 & 0,7 & 0,4 \\
\hline $1 Z$ & 0,7 & 0,5 \\
\hline $2 Z$ & 0,7 & 0,5 \\
\hline $3 Z$ & 0,6 & 0,5 \\
\hline
\end{tabular}

with the use of TROTEC BM22 device.

\begin{tabular}{|l|l|l|}
\hline & \multicolumn{1}{|c|}{ April 10th 2019 } & \multicolumn{1}{c|}{ June 12th 2019 } \\
\hline $\begin{array}{l}\text { MEASURMENT } \\
\text { POINTS }\end{array}$ & $\begin{array}{l}\text { W } \\
\text { Wall humidity } \\
\%\end{array}$ & $\begin{array}{l}\text { W } \\
\text { Wall humidity } \\
\%\end{array}$ \\
\hline 1 & 0,7 & 0,4 \\
\hline 2 & 0,7 & 0,4 \\
\hline 3 & 0,7 & 0,4 \\
\hline $1 Z$ & 0,7 & 0,5 \\
\hline $2 Z$ & 0,7 & 0,5 \\
\hline $3 Z$ & 0,6 & 0,5 \\
\hline
\end{tabular}



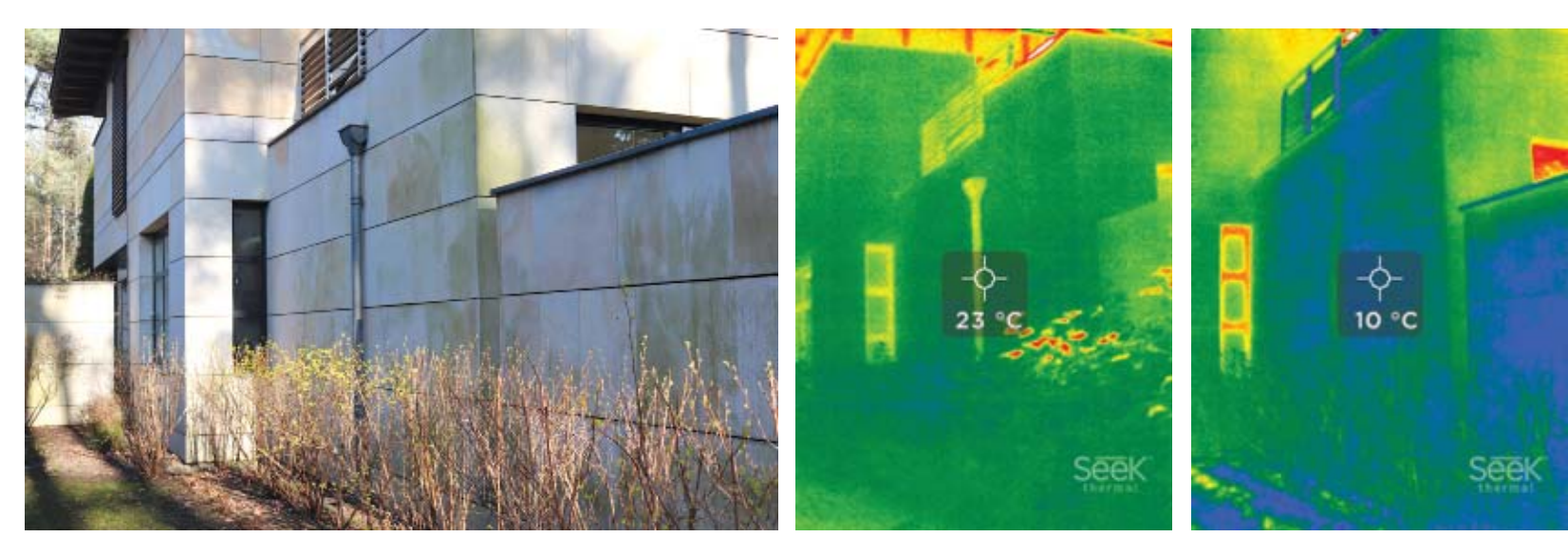

8. fragment budynku nr 4 pótnocno-zachodnia elewacja, fot. J. Klimowicz / the fragment of the building no 4, west- north elevation, photo J. Klimowic 1I. 9. kamera termowizyina 10 kwietnia 2019 r., fot. J. Klimowicz/ thermal camera April 10't 2019, photo J. Klimowicz

Badanie kamerą termowizyjną Seek Thermal przeprowadzone były we wszystkich punktach pomiarowych,
poniżej przykład jednego punktu pomiarowego $z$ dnia 10 kwietnia i 12 czerwca 2019 r. (zdjęcie badanego budynku $\mathrm{nr} 3$ oraz wynik pomiaru kamerą termowizyjna w punkcie 1Z)

\section{Wnioski}

Z badań przeprowadzonych miernikiem punktu rosy wy nika, iz w badanych punktach pomiarowych budynki nie wykazują zmian związanych z roszeniem. Nie występuj w nich groźne dla konstrukcji skraplanie wody, jest to jednoznaczne z niewystępowaniem zawilgocenia i ewentualnego zagrzybienia przegród. W badanych punktach średnia temperatura roszenia jest zawsze niższa niż temperatura na powierzchni przegrody oraz temperatura powietrza. Pomiary miernikiem wilgotności potwierdzity stabilność ścian. Wyniki zebranych danych wykazały, iz ściany wykazują wyższa wilgotność na zewnątrz niż we whątrz budynku. Jest to zgodne z przesunięciem punktu rosy $w$ przegrodzie poza ele z Kamera termowizyin

Wyizyjna wykazała, iż źle izolowane i niemizina stwarzaja warunki dyskomfortu dla Wrín badań przeprowadzonych w pomieszkáców co do komfortu zamieszka U Utrzmuja ce sie wysokie temperatury zewnetrznego powietrza bez odpowiednej izolacji termicznej wpływają na podnoszenie sie temperatury we wnetrzu, powodujac dyskomfort. Podobnie zachowuja się w okresach zimowych, kiedy to oddając energię cieplna na zewnętrz powoduja wyzie bienie wnetrz oraz podwyższenie temperatur zewnetrza. Przyczynia się to do wzrostu występowania efektu Miejskiej Wyspy Ciepła. Istotne zatem jest stosowanie izolacji termicznej oraz dobór odpowiednich materiałów oraz przeszklenia okien

W dobie dzisiejszych zmian klimatycznych, zwłaszcza coraz częsciej obserwowanego i badanego wzrostu temperatury na swiecie, istotnym jest, aby stwarzac korzystne warunki zamieszkania. Dobrze zaizolowane i szczelne budynki z jednej strony chronią przed nadmiernym ing camera was carried out at all measuring points, below is presented the example of one measuring point on April 10 th and June 12th 2019. (photo of the building no. 4 and the result of the themar camera measurement in point 1Z)

\section{Conclusions}

The research carried out by the dew point gauge shows the buildings in the surveyed measurement points do water condensation dangerous for the structure. This is tantamount to no moisture and possible fungus of walls. In the examined points, the average dew temperature is always lower than the wall surface temperature and air temperature. Measurements with a humidity meter confirmed the stability of walls. The results of the midity outside than inside the building. This is consistent with the shift of dew point in the partition outside the structural element to outside the partition.

The thermal imaging camera showed that poorly insulated and leaky buildings create conditions of discomfor for the residents. The results of the research carried out in particular buildings coincide with the observations of esidents as to the comfort of living. Maintaining high emperatures of external air without adequate therma nsulation affect the increase of temperature in the inteior causing discomfort of living. They behave similarly in winter periods, whe they impley be in with and incere the temper in the the the of ite malis lation and selecion of ap is in mal insulation and selection of appropriate materials and glazing of windows.

today's times of climate change, especially the creasingly observed and researched the rise of global temperature, it is important to create favorable powania efektu Miejskiej Wyspy ciepła, jak też mi-

[B.A.] Stownik Jezzyka Polskiego źródto https://sjp.pwn.pl/slowniki Woiciech, Krecisz Beata, Btazeiczyk Anna, Szmyd Jakub De, Dudek not have any changes related to dewing. There is $\mathrm{no}$ collected data showed that the walls show higher hunarne. Wydawnictwo CeDeWu, Warszawa, 2018 r., ss. 59-82. ctwo Uniwersytetu tódzkiego, tódí 2003r.
[4] Gehl .., The challenge of creating a human quality in the city, nimalizują przegrzewanie się wnętrza w okresach podwyższonych temperatur.

PRZYPISY

Mokyr, J. (1999). The Second Industrial Revolution, 1870-1914, w:

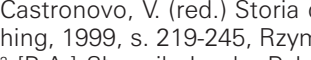
'B.A. Cambridge Dictionary źródto https://dictionary cambridge org dostep 15.04.2019 hasto komfort

"Wisniewski Tomasz, fragment wykladu pt ,Komfort cieplny", , źród-
to www.tc. pw.edu. pl/content/downaload hasto komfort cieplny data to www.itc.p Bańka, Augustyn (2018). Psychologiczne konteksty jakości życia

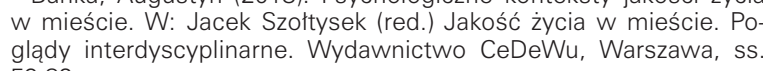
$59-82$.
6 EAA- Europejska Agencia środowiska

IPCC - Miedzynarodowy Zespót ds. zmian klimatu jest organem
Organizacji Narodów Zjednoczonych zajmującym się oceną nauki zwiazanej ze zmianami klimat

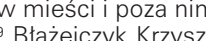
Bozena, Pałczýński Cezary, „Miejska wyspa ciepła w Warszawie",

living conditions. Well insulated and airtight buildings, on the one hand, protect against excessive heat losses, whic also increase the occurrence of the City Heat Island effect, and minimize overheating of the interior in periods of increased temperatures.

Mokyr, J. (1999). The Second Industrial Revolution, 1870-1914, w: Ca1999, s. 219-245, Rzym. step 15.04.2019 password comfort Ite. A. Cambridge Dictionary source https:///dictionary.cambridge.org doWiśniewski Tomass, lecture piece titled „Komfort cieplny", source
"www.tct.pw.edu.pl/content/downaload password komfort ciepiny data 13.052019 Bańka, Augustyn (2018). Psychological contexts of the quality of life in he city. In: Jacek Szottysek led.) Quality of life in the city. Interdisciplinary VEA- Europent

IPCC - The Intergovernmental Panel on Climate Change (IPCC) Is the Un Urban Heat Island - a phenomenon connected with temperature diffe ences inside and outside of it Magdalena, Milewski Pawet, Dudek Woalczyński Cezary, „Urban Heat Island in Warsoww", Sedno Acórsa Bozezena

LITERATURA

[1] Bańka A., Psychologiczne kontekstr jakości iycia w mieście, W:

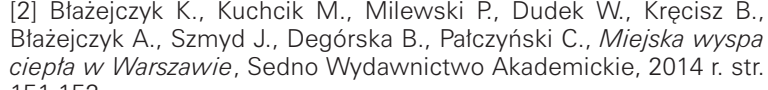

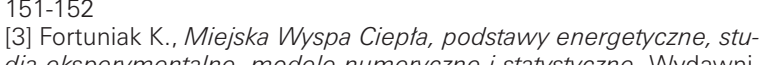

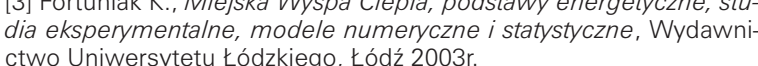
1995", Exeter.
[5] Mokyr J., The Second Industrial Revolution, 1870-1914, w: Castronovo, V. (red.) Storia dell'economia Mondiale. Laterza publishing. [6] Montgomery Ch., Miasto szcześlive. Jak zmienić nasze życie, zmieniajac nasze miasta, Wysoki Zamek, Kraków, $2015 \mathrm{r}$ r
[7] Nikolopoulou M., Baker N., Steemers K., Thermal comfort in

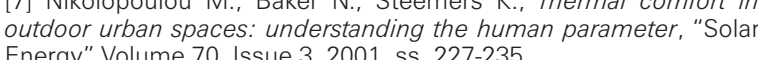

BIBLIOGRAPHY

11) Bańka A., Psychologiczne konteksty jakości iycia w mieście, W: Jacek cawnictwo CeDeWu, Warszawa, 2018 r., ss. 59-82.

Kręcisz B., Btaziejczyk wie, Sedno Wydawnictwo Akademickie, 2014 r. str. 151-152

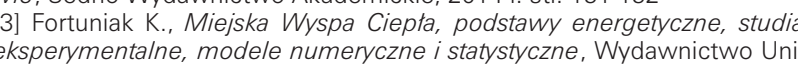
wersytetu Łódzkiego, Łódź 2003r.

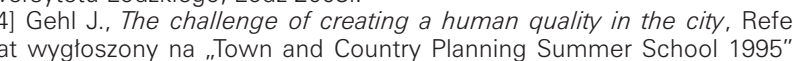
Exeter.. The Second Industrial Revolution. 1870-1914, w: Castronovo. V. (red.). Storia dell'economia Mondiale. Laterza publishing, Rzym 1999 6] Montgomery Ch., Miasto szczesśliwe. Jak zmienić nasze życie, zmieni

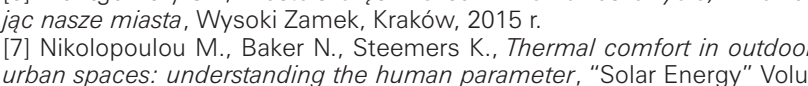
urban spaces: understanding the hu
me 70, Issue 3, 2001, ss. 227-235 